\title{
Influence of Community Participatory Mobilization on Attitude of Farmers Towards Deforestation in Cross River Rainforest Zone Nigeria
}

\author{
OMARI $^{1}$, AGNES O OMOOGUN ${ }^{2}$, REMI M EFFIOM ${ }^{2}$, JOHN. E. \\ 1. National Oil Spill Detection and Response Agency, Abuja \\ 2. Department of Environmental Education \\ University of Calabar, Nigeria
}

\begin{abstract}
The main purpose of this study was to examine community participation and attitude of farmers towards deforestation in the rainforest zone of southern Cross River State, Nigeria. To achieve the purpose of this study one hypothesis was formulated to guide the study. Ex-post facto research design was considered most suitable for the study. A sample of 568 respondents was randomly selected for the study through stratified and simple random sampling techniques. A structured questionnaire was the instrument used for data collection. The instrument was faced validated by three experts in Test and Measurement and the research supervisor who vetted the items developed. The reliability estimate of the instrument was established through the Cronbach alpha reliability method. Simple linear regression statistical tool was used for data analysis. The results of the analysis revealed that, there is a significant influence of community participatory mobilization on attitude of farmers towards deforestation in rainforest zone in the study area. Based on these finding it was recommended among others that environmental educators and advocates should ensure community participation to empower them to develop more positive attitude towards eradication of negative environmental practices and actions.
\end{abstract}

Keywords: community participation, environmental awareness, attitude, deforestation, rainforest

DOI: $10.7176 /$ CER/11-6-02

Publication date:July $31^{\text {st }} 2019$

\section{Introduction}

Forest is a biological community consisting of complex association of trees, plants, water sources and soil that have evolved over millions of years, providing habitats for millions of plants and animal species. The forest is directly threatened by depletion and degradation of the natural resources on which plants depend. Some 20,000$50,000 \mathrm{~km}^{2}$ of potentially productive lands is lost annually worldwide through deforestation. The activity affects the protective, productive and regulatory functions of the forest on a global perspective; many more have reduced the vegetative cover where 2-9 million $\mathrm{km}^{2}$ of the earth crust is said to be at very high risk of the resultant impact of desertification, food shortages, global warming etc. (FAO,2012]

Deforestation is the conversion of forest to an alternative non- forest use. Currently deforestation constitutes major environmental problems. Eneji, Ogar, Essien and Bullem (2014) have pointed out that approximately $78 \%$ of the forest cover in the world have disappeared in the last two decades due to various activities of farmers, ranchers and the multinational companies; this forest has been cleared for logging, timber export, subsistence agriculture, collection of hardwood for fuel and $82 \%$ of the hardwood exploited in the forest suffered lost annually and these remains problematic in West Africa.

The Nigerian environment since the attainment of independence in 1960 has grown rapidly from a predominantly primary production based economy to an industrialized one among other countries of the world today presents a grim litany of woes, where every state of the federation suffers from one form of environmental problems or the other in varying degrees. According to Food and Agricultural Organization (2005) Nigeria destroys about 600,000 hectares of land every year through indiscriminate exploitation and husbandry. Such careless exploitation of forest has implications in a number of worsening environmental problems in the country, including soil erosion and infertility, desertification and flooding.

There is rapid disappearance of tropical forest as human clears the natural landscape for farming and pastures, harvesting timber for construction of roads and urban areas (Robert, 2007). The author further said that deforestation meets human needs but also has some devastating consequences such as social conflict, extinction of plants and animals species and climate change that presents challenges not just local but global. However, it was observed that accelerating destruction of the rainforest that form a precious cooling band around the earth's equator is now being recognized as one of the main causes of climate change.

Food and Agricultural Organization (2010) reports that the tropical rainforest capture most attention on deforestation during 1990 and 2010; Nigeria lost an average of 409,700 hectares of forest cover between 1990 and 2005 , which is estimated at $35.7 \%$ (Odihi, 2013). The highest rate of primary forest lost and climate change may increase by $41.2 \%$ between 2000 and 2010 if care is not taken (FAO, 2007). However, Nigeria case is even 
more worrisome as about $85 \%$ of the rural populace and about $78 \%$ of the urban population are extremely poor and live in squatter settlements, while about $73 \%$ of the entire Nigerian population lives below the UN $\$ 1$ per day limits, hence these poor households draw from the forest for their survival Oates, Mcfarlan, Groves, Bergl, Linder, and Distell (2003); Oloruntoba \& Adetokumbo, (2006) and Ogunjobi, Meduna, Oni, Inah and Enya, (2010).

Cross River State is blessed with abundance of resources to improve lives. In a bid to promote or encourage development, several devices have been invented to enhance agricultural, industrial and transportation activities. These activities, while providing the raw materials for production of goods and services have also resulted in pollution of land, atmosphere, vegetation and rivers (Philip, Harrison, Akintoye, Olorundami, Nkpena \& Ukata, 2014). The authors further stressed that forest disappearance in Southern Cross River State has been blamed on agricultural activities which have promoted the cutting down of trees, and the burning of bushes before cultivation takes place.

Though there seems to be several kinds of human activities that may promote human sustainability in the Southern part of Cross River State, yet many people mostly the indigenes engage in agricultural activities for their survival. Even those who engage in these industries like the quarry industry, cement industry and other businesses, still cultivate parcels of land to support their families. In the late 80s and early 90s, there were still pockets of forests that housed several millions of lives, but industrialization and widespread agricultural activities have destroy the forest due to negative concept towards the environment. Attitude is ones disposition or reaction towards event.

Philip et al (2014) pointed out that $19 \%$ of the tropical forest zone has been lost through deforestation. Hence, the need to adopt sustainable conservation of forest practices. Serious awareness campaign should be created by the government and environmentalists on the important role played by the forest. The current National Tree Planting Campaign is a mere ritual as well as a radio, television propaganda which should be redesigned and the negative impact of deforestation made known to the masses to stem the tide of biodiversity loss. Governmental agencies and non-governmental organization (NGOs) like Nigerian Conservation Foundation (NCF), Federal Ministry of Environment (FME), Federal Environmental Protection Agency (FEPA), National Parks, the National Resources Council (NARECO), in collaboration with the United Nations Environmental Programme (UNEP), the World Wide Fund (WWF), and other several agencies have embarked on numerous projects aimed at preserving the Country's biodiversity (Anijah-Obi 2001). However, not much has been achieved as Nigeria keeps losing its forests, wildlife and plant species. Citing Ribot, Citing Ribot, Jallah et al (2017), noted that the marginalized and disadvantaged people of the community plays greater role in natural resource management if they are well empowered. Similarly, World Bank report recommended Bottom-up community mobilization that has shown to be an important factor in making communities more successful in confronting poverty and disempowerment (World Development Report 2000/2001)

Community participatory mobilization refers to people's engagement within the community that plays an essential and long-standing role in protecting quality of life. This involvement of community members in matters concerning forest maintenance would improve the sustainability of the forest for future generation. Bhaff (2008) articulates that community participation is a process and not simply the sharing of social and economic benefits. This implies that participation of local community in natural resources management is the integration of local people to mobilize themselves to make decisions, manage their resources and control the activities that affect their lives. The involvement of local community in forest management is vital given that the people are dependent upon the forest for their livelihoods. People who live close to forests and may be dependent on them for a variety of products and services have greater interest in the proper management than distant authorities located hundreds of kilometers away [Pulhin, Inoue \& Enters 2007].

The process of increasing peoples' knowledge and enlightenment on the environment and challenges as well as acquire the relevance skills to effectively manage the environment is referred to as environmental awareness strategy (Arcury, 2000).

The agents of deforestation are those slash and burn farmer's activities, commercial farmers' ranchers, loggers, firewood collectors, infrastructure developers and others who are cutting down the forest. There is an increase in resource extinction and depletion in most rural communities in Nigeria. The need to improve farming activities has increased demand for fertilizer application by farmers. The use of artificial manure and its attendant problems may render the soil barren after a relatively long period of time of its use. This practice overtime may lead to the destruction of micro and macro-organisms that their activities are necessary and significant in the eco-system. In the same way, plant species that are supposed to be preserved may not be spared. Other driving factors include poverty, population growth, unstable land-tenure system, property right over forests and lack of forest and land-use policies (Yirdaw, 2002).

\section{Statement of the problem}

Despite the contribution, forest resources of the wellbeing of most communities, there have been deteriorating 
of the forest size and quality with the attendance effects of depleting the potentials of its resources.. The annual rate of deforestation as currently estimated is alarming and very unsustainable.

The need for farmers to develop positive attitude towards reduction in deforestation has become necessary. This is because most agricultural practices and other human activities such as slash and burn agriculture, hunting with regular setting of forest ablaze, over grazing and continuous farming are some of the ways by which farmers deprive the rainforests of its natural resources. Rapid degradation and natural resources depletion has continued to be a subject of concern. The rate of forest destruction has accelerated significantly since the turn of the $21^{\text {st }}$ century.

In Southern Cross River State between 2000-2005 about 30,000 hectares of forest areas have been cleared down for several purposes: road construction, housing estate, erosion control, road expansion and agricultural plantation. The greatest destruction of resources is caused by exploration, excavation and blasting of stones which has greatly affected and led to depletion of forest resources. The removal of forest has significant negative implications on the environment and human beings. The consequences of these unsustainable forest practices include global warming, drought, flooding, loss of biodiversity, flora and fauna, loss of fertile land required for improved food production and so on. More importantly is that many communities that solely depend on the forest will lose the sources of their livelihood.

The efforts of government and Non-Governmental Organization to control the unwanted destruction of forest resources and its consequences have not yielded desired results. This unfortunate situation may be attributed to attitude of rural farmers towards forest resources. Government in the past has created avenues to educate the farmers on sustainable use of the forest and gradually involved the communities in reducing the incidence of deforestation. The question however, remains; what influence has community participatory mobilization on attitude of farmers as regards their continued unsustainable use of the forest? This is the problem to which the study seeks solution to.

\section{Research question}

To what extent does community participatory mobilization influence the attitude of farmers towards deforestation?

\section{Statement of hypothesis}

Community participatory mobilization does not significantly influence the attitude of farmers towards deforestation

\section{Literature}

Resource protection and management may be possible if community members are allowed participation or involvement in the protection and management of their resources. Lepetu and Gerekae (2015) ascertained that in many parts of the world, state management of forest has been criticized for ignoring local community participation in forest management and failing to recognize local communities' needs for forest products. The situation in which little consideration was given to the people's long term needs; local people lose the feeling of owning the forests and develop negative attitudes towards them. This in turn leads to indiscriminate exploitation of forests, degradation and deforestation.

Ogar (2003) is in the same view with the authors stemming above, that local community are supposed to be involved in resource management through the process of gradually handling over the harvesting and management activities. Government role in natural resource management should be focused in evaluation of the initiative of local people, state and the institutions involved in promotion of extension services that is of immense benefits to the community. The author further categorized three different ways in which communities can participate in forest management such as community based management, collaborative management of forest resources and the use of customs and traditions of a community.

Over the past decades, there has been increase in number of NGOs, with interest in forestry issues. Such non-governmental organizations (NGOs) in Nigeria collaborate with the government institutions to ensure sustainable forest development, support the immediate needs and priorities of local people, assist in resources planning and implementing forestry programmes. Among the NGOs are; Nigerian Environmental Study Action Team (NEST), Nigerian Conservation Foundation (NCF), Nigerian Field Society (NFS), Coalition for Environment (CFE) and Worldwide Fund for Nature (WWF).

Isiugo and Obioha (2015) carried out a study on Community Participation in Wildlife Conservation and Protection in Oban Hills Area of Cross River State, Nigeria. The purpose of the study was to examine the nature and extend of Community-based Wife Management in the area by identifying an effective ethical way of integrating the goals of wildlife conservation with the needs of the rural poor in the tropics. A descriptive survey method was used to collect data; five (5) villages were selected based on their proximity to the park while simple random sampling technique was used to draw a sample of 288 respondents. Data was obtained through 
interviews guides and questionnaires with the participants in the environment. The findings of the analysis indicate that community leaders and the youth play key roles of educating their members on the importance of wildlife conservation and guarding their forests from poachers respectively.

The analysis further revealed that the community members do not benefit from wildlife conservation efforts by the Federal Government; the implementation of laws prohibiting hunting in the protected area and harvesting of conserved animal species in forests in the buffer zone has negatively affected the livelihood of heads of households and male youth who were great hunters. The authors suggested that Community institutions enforcing taboos and totem related to killing and eating of wildlife and non-governmental organizations or conservation societies, community leaders and youth should be strengthened and officially recognized as partners who derive significant benefits from wildlife management in the area.

The finding of the above reviewed study was considered of relevance to this study's review based on the recommendation of the researchers that the Cross River National Park (CRNP) should enforce policy through public enlightenment, arrest of violators and liaises with other government agencies and enforcement of local taboo within the communities. Furthermore, the policy should be made in consultation with the people in order to make it look homegrown.

In a study designed to investigate the attitudes of local communities towards Community Forestry Programmes implemented in Kosti area by Kobball (2012) who utilized a survey research design. The study's population comprised of 100 people living in ten villages while random sampling technique was applied to select a sample of 10 respondents from each village. Questionnaires were used to obtain information from the respondents. Data analysis was done using multiple linear regressions. The analysis showed a statistical significant relation between some selected variables like respondents knowledge, family uses of different forestry products, awareness of causes of forest destruction and respondent's awareness of environmental problems, which exerted important influences on the attitudes, and participation of respondents. The results further showed that almost all the respondents have a particular favorable perception of the community forestry programmes implemented and they perceive the best type of management for running these forests which is to be owned and managed by them.

According to the researcher, farmers posed positive attitudes towards community forestry although they were not fully involved in community practices, that they also participated in different program activities and willing to further participate in tree planting activities. The study recommended that the forest service's should continue addressing local development needs, encourage farmer's participation in community forestry and work toward dispute settlement of community forest user groups, if it wants to win the support of local communities for long term environmental conservation goal. This seems to imply that the community participation mobilization is very necessary in forest protection and management.

The study of Kobball (2012) found relevance to the present study as a result of its investigation on how extension officers should treat farmers as people with valuable information and knowledge about the local environment by organization of regular workshops. This knowledge is vital for providing insights on how the needs of people can be met, which includes maintaining sound environmental condition. Sustainable forest as seen by Anukwa (2002) would be a goal unaccomplished without the development of forest management plans for target communities. He stresses that the essence of the plan was to ensure effective and rational use of timber and non-timber forest resources in Cross River State. Forest management may also encompass the careful use of land, air, water, plants, and animal resources.

Community participation brings about conservation of our economic human, animal, aquatic and other forest resources leading to a sound health and sustainable environment in the future because protection emphasizes preservation, maintenance culture, sustainable utilization and enablement of natural environment. The government in collaboration with forest commission has encouraged communities to participate in the management of their forest. The constituted Cross River State Forestry Commission Board has been charged in the state to efficiently harness or develop/conserve and managed for sustainability for the benefits of all stakeholders. The community forestry support unit (CFSU) is mandated to create the enabling environment for the stakeholders to derive maximum benefit from the forests.

Bassi, Monguno and Joseph (2017) carried out a research on Community Participation in Environmental Conservation and Protection in Kida Community, Hawul of Borno State, Nigeria. The purpose of the study is to access the environmental management system in the areas especially community involvement in protecting the environment. The population of the study constitutes 120,733 with a sample of 150 respondents using questionnaires for data collection. The research focused on group discussion and in-depth interviews. The finding revealed that there is a significant deference between problems associated with indiscriminate tree felling, bush burning, overgrazing and ignorance among community members willingness in participation.

Bassi et al (2017) recommended among others that Government important role is to boost community participation through replanting of trees, patrolling and employment of conservation workers. In addition public enlightenment should be given consideration to the community on the danger of not protecting and conserving 
the environment. Department of natural resources and agriculture in the area should involve community to participate in environmental protection and conservation. This will increase dissemination of information and more awareness in the rural populace.

In a study by Palmer (2006) community based youth participation in the fragile areas in Sierra Leone shows that, people migrated from the provinces to an already over populated free-town. Population pressure on the coastal lands of free town caused the clearing of large expanse of land on the steep slopes surrounding the city for urban settlement, construction, farming, and collection of firewood. To remedy this, a green belt programme for the replanting of some 710 hectares of degraded lands was carried out. Now the result has been satisfactory because about 154 hectares of targeted land was replanted. Forest incentives are some of those tools that can be employed to promote sustainable forest management in the rural communities. Several incentives that can boost forest management have been outlined to include tax incentives, increase community development, and increase in royalty to communities and employment opportunities. All these strategies are developed to stimulate community participation in resource management.

\section{Methodology}

The research design adopted for this study was Ex-post facto design. Isangedighi, Joshua, Asim and Ekuri (2004) asserted that Ex-post facto research design is a systematic empirical inquiry in which the researcher does not have direct control of the independent variables because their manifestations have already occurred or because they are inherently not manipulated. Inferences about relationships among variables are made without direct intervention from concomitant variation of independent and dependent variables.

The stratified random sampling technique was used for the study. The stratification was based on the seven local government areas. In each of local government areas the simple random sampling technique was used to select the sample for the study. 50\% of the local government area, which is four, was used for the study.

In selecting the communities used for this study, the simple random sampling technique was adopted. This was done through multi- stage sampling procedure. The researcher consulted the council of chiefs of each of the four local government areas to know the names and number of communities that make up each of the local government areas that were selected for the study.

. Through this method, community members within the various categories needed for the study who were willing to participate in the study were selected and used.

The instrument used for data collection in the study will be the questionnaire. It will be tagged Environmental Awareness Questionnaire (EAQ) and Attitude of Farmers towards Deforestation Questionnaire (AFTDQ). It was divided into two parts. Part ' $A$ ' contained two items on respondents' personal data which include name of village and name of Local Government Area. Part ' $B$ ' was designed using four point Likert scale of strongly agree (SA), Agree (A), Disagree (D) and strongly disagree (SD). It contained 15 items that measured the sub- variables of the independent and dependent variables.

Cronbach Alpha reliability method was adopted in ensuring the reliability of the rsearch instrument. The researcher administered 50 copies of the questionnaire to respondents in two communities in the study area that were not part of the actual study. The researcher administered the instrument once to the respondents. The data obtained was analysis to determine the internal consistency of each item in the questionnaire. The Cronbach alpha coefficient result obtained from the analysis of data is .821 , which showed high reliability of the research instrument.

Data used for the study was obtained directly from respondents selected. In each of the communities selected for the study, the researcher visited the chiefs to take permission before administering copies of the questionnaire. The researcher used two trained Research Assistants to visit all the communities selected for the study for the administration of the questionnaire. The administered copies of the questionnaire were retrieved.

\section{Result and Discussion}

Community participatory mobilization does not significantly influence attitude of farmers towards deforestation. The independent variable in this hypothesis is community participatory mobilization while the dependent variable is attitude of farmers towards deforestation of rainforest in Southern Cross River State. Simple regression statistical tool was used for data analysis. The result of this analysis is presented in Table 1 
TABLE 1

Simple regression analysis of the influence of community participatory mobilization on attitude of farmers towards deforestation in Southern Cross River State $(\mathrm{N}=568)$

\begin{tabular}{|c|c|c|c|c|c|}
\hline Model & $\mathrm{R}$ & $\mathrm{R}^{2}$ & Adj. $R^{2}$ & \multicolumn{2}{|c|}{ Std error of estimate } \\
\hline 1 & .235 & .055 & .054 & \multicolumn{2}{|c|}{8.59680} \\
\hline \multicolumn{6}{|c|}{ REGRESSION ANOVA } \\
\hline Model & $\mathrm{SS}$ & Df & MS & $\mathrm{F}$ & Sig \\
\hline Regression & 2450.371 & 1 & 2450.371 & 33.156 & .000 \\
\hline Residual & 41830.249 & 566 & 73.905 & & \\
\hline Total & 44280.620 & 567 & & & \\
\hline \multicolumn{6}{|c|}{ REGRESSION COEFFICIENTS } \\
\hline & \multicolumn{2}{|c|}{$\begin{array}{l}\text { Unstandardized } \\
\text { coefficients }\end{array}$} & $\begin{array}{l}\text { Standardized } \\
\text { coefficient }\end{array}$ & $\mathrm{T}$ & Sig \\
\hline & $\mathrm{B}$ & Std error & Beta & & \\
\hline (Constant) & 14.491 & 1.445 & . & 10.027 & .000 \\
\hline Funding & .568 & .099 & .235 & 5.758 & .000 \\
\hline
\end{tabular}

The result of analysis presented in Table 1 showed that the predictor or independent variable (community participatory mobilization) significantly influences the predicted variable (attitude of farmers towards deforestation). The influence is significantly positive (33.156). The regression coefficient showed that community participatory mobilization $(\beta=.235 ; \mathrm{t}=5.758 ; \mathrm{p}<.05)$ is statistically significant in the prediction of attitude of farmers towards deforestation of rainforest in Southern Cross River State.

It was revealed from the finding obtained from analysis and testing of hypothesis that the null hypothesis was rejected. This implied that there is a significant influence of community participatory mobilization on attitude of farmers towards deforestation of rainforest in Southern Cross River State. This finding agrees with the finding of Lepetu and Gerekae (2015) which reported that resource protection and management may be possible if community members are allowed participation or involvement in the protection and management of their resources. In many part of the world state management of forest has been criticized for ignoring local community participation in forest management and failing to recognize local communities' needs for forest products. The situation in which little consideration was given to the people's long term needs; local people lose the feeling of owning the forests and develop negative attitudes towards them. This in turn leads to indiscriminate exploitation of forests, degradation and deforestation.

The finding of this study also supported the finding of Ogar (2003), which revealed that local communities are to be actively involved in resource management within their communities. Government's role in natural resource management should be focused on evaluation of the initiative of local people, state and the institutions involved in promotion of extension services that is of immense benefits to the community. The author further categorized three different ways in which communities can participate in forest management such as community based management, collaborative management of forest resources and the use of customs and traditions of a community. Over the past decades, there has been increase in number of NGOs, with interest in forestry issues. Such non-governmental organizations (NGOs) in Nigeria collaborate with the government institutions to ensure sustainable forest development, support the immediate needs and priorities of local people, assist in resources planning and implementing forestry programmes. Among the NGOs are; Nigerian Environmental Study Action Team (NEST), Nigerian Conservation Foundation (NCF), Nigerian Field Society (NFS), Coalition for Environment (CFE) and Worldwide Fund for Nature (WWF).

The need to mobilize people towards participation in environmental protection and management has become imperative in the midst of increasing incidence of environmental degradation. Environmental awareness has been identified as a viable tool for actualizing this goal. An uninformed citizen lacks the requisite knowledge, attitude and skills for sustainable environmental protection and management. This emphasizes the need for increased awareness levels towards raising a citizenry that is aware of the total environment and its associated problems, as well as possesses the skills and commitment required to participate in the conservation of the environment.

\section{Recommendations}

The researchers proffered the following recommendations;

i. Members of forest communities should be continually mobilized to participate actively in planning and management of the forest especially in order to change negative attitude towards deforestation among members of these communities

ii. The use of traditional media should be encouraged in order to diversify the medium through which 
environmental information is disseminated for continuous attitudinal change among members of forest communities.

iii. Community should have the opportunity participate in discuss with all stakeholders on the benefits of conserving the forest and what they stand to benefit in forest conservation.

\section{References}

Anijah-obi, F. N. (2001). Environmental education: planning process and management. Calabar, University of Calabar Press.

Bassi, W. S., Mongune, A. K., \& Joseph, S. B. (2017). Community participation in environmental conservation and protection in Kida community: Haww Loca Government Area of Borno State, Nigeria. Asian Journal of environment and ecology, 2 (3), 1-11.

Bhaff, H. I. (2008). Effective communication and environmental resource management. Uganda: Mondie Communications.

FAO. (2007). Deforestation in developing countries of the world. Rome: Food and Agricultural Organization

FAO. (2012). The State of food insecurity in the world: Economic growth is necessary but not sufficient to accelerate reduction and malnutrition. Rome: Food and Agricultural Organization

FAO. (2010). Sustainable crop production intensification through an ecosystem approach and an enabling environment capturing efficiency through ecosystem servicers and management $22^{\text {nd }}$ session of the FAO committee on agriculture, 16-19, Rome.

FAO. (2005). Global forest resource assessment: Forest facts by countries. http://www.FAO.org./forestry /32185/en/nga.

Isangedighi, A. J., Joshua, M. T., Asim, A. E., \& Ekuri, E. E. (2004). Fundamentals of research and statistics in education and social sciences: Calabar: University of Calabar Press.

Isiougo, P. N., \& Obioha E. E. (2015). .Community participation in wildlife conservation and protection in Oban hills area of Cross River State, Nigeria. Journal of Sociology and Anthropology, 6 (2), 279-287

Jallah , C.K; Amoakoh, A.O; Boateng, K; Nortey, D.N \& Assumadu, R. (2017), Community participation in forest management in the Bleih community forest, Nimba county, Liberia. North Asian International Research Journal of Multidisciplinary. 3, (1).3-22

Kobball, A. A. R. (2012). Local people's attitude towards community forestry practices. A case study of Kosti province - central Sudan: International Journal of forestry research, 10, 1-7.

Kyeremeh, F. K. (2015). Community Participation in Forest Management of Kakum Conservation Area of Central Region. Statewide Agricultural Land Use Baseline 2015. University of Cape Coast.

NGO. (2008). Perspectives on environmental management. Uyo: Environment system club inc.

Oates, J. F., Mcfarland, K. L., Groves, L. L, Bergl, R. A., Linder, J. M., \& Distell, T R. (2003). Protecting forest fauna in Cross River State, Nigeria, in: Taylor, A. B; \& Goldsmith, M. L. eds the Cross River Gorilla; Natural History and status of a neglected and critically endangered subspecies. Cambridge, UK Cambridge Universities press.

Odihi, J. (2003). Deforestation in afforestation priority zone in Sudano-Sahelian Nigeria. Applied Geography, 23 (4), 227-239.

Ogar, H. M. (2003). Environmental conservation and management handbook. Lagos: Tanus publishers.

Ogunjobi, J. A. Meduna, A. J., Oni, S. O., Inah, I. E., \& Enya, D. A. (2010). Protection of staff job perception in Cross River National Park, Southern Nigeria, Middle-East. Journal of scientific research, 5, 22-27.

Oloruntoba, A. and Adetokumbo, O. (2006). Determinants of household's participation in social forestry in a zone of northern Nigeria Journal of food. Agriculture and environment, 4 (2), 320-326.

Palmer, S. M. (2000). Environmental planning: Perception and behaviour. Boston: Houghton Muffin.

Philip, F., Akintoye, O. A., Olorundami, T., Nkpena, C. O., Ukata, S. U., \& Harrison, E. U. (2014). Forest resources of Cross River State: Potentials, threats and mitigation measures. Journal of Environmental Science, Toxicology and food Technology, 8 (6), 64-71.

Pulhin JM, Inoue M, Enters T (2007) Three Decades of Community-Based Forest Management in the Philippines: Emerging Lessons for Sustainable and Equitable Forest Management. International Forestry Review 9: 865-883.

Ribot, J. C., (2004). Waiting for democracy: the politics of choice in natural resources decentralization, Washington, DC: World Resources Institute.

World Development Report 2000/2001, Attacking Poverty, The World Bank Group, Washington, D.C., 2000.

Yirdaw, E. 2002.Restoration of the native woody-species diversity, using plantation species as foster trees, in the degraded highlands of Ethiopia.Doctoral thesis.University Helsinki Tropical Forest Re.24. 